\title{
How does EGFR overexpression affect the development and treatment of rectal cancer?
}

\section{W jaki sposób nadekspresja EGFR wpływa na rozwój i leczenie raka odbytnicy?}

\author{
Monika A. Kozłowska-Geller1, Piotr Lewitowicz², Stanisław Głuszek ${ }^{3,4}$ \\ ${ }^{1}$ Department of Physiology, Institute of Medical Science, Faculty of Medicine and Health Science, Jan Kochanowski University, Kielce, \\ Poland \\ Head of the Department: Prof. JKU Anna Polewczyk MD, PhD \\ ${ }^{2}$ Department of Pathology, Institute of Nursing and Obstetrics, Faculty of Health Sciences, Jan Kochanowski University, Kielce, Poland \\ Head of the Department: Prof. Anna Nasierowska-Guttmejer MD, PhD \\ ${ }^{3}$ Department of Clinic General Oncological and Endocrinological Surgery, Regional Hospital, Kielce, Poland \\ Head of the Department: Prof. Stanisław Głuszek MD, PhD \\ ${ }^{4}$ Department of Surgery and Surgical Nursing with the Scientific Research Laboratory, Institute of Medical Sciences, Jan Kochanowski \\ University, Kielce, Poland \\ Head of the Department: Prof. Stanisław Głuszek MD, PhD
}

Key words: colorectal cancer, EGFR, monoclonal antibodies.

Słowa kluczowe: rak odbytnicy, EGFR, przeciwciała monoklonalne.

\begin{abstract}
Epidermal growth factor (EGF) stimulates the proliferation of many different types of cells and plays an important role in the formation and growth of tumours. The interaction of EGF with cells is possible by the EGF receptor (EGFR) anchored in the cell membrane. Excess EGFR expression is found in approximately $25-82 \%$ of colorectal cancer cases. Attachment of EGF to EGFR results in a conformational change in the receptor, an increase in affinity for neighbouring receptors, receptor dimerisation, and activation of tyrosine kinase in the intraplasmic domain. Activation of EGFR leads to the initiation of the signal transduction pathway to the cell nucleus, via a number of proteins with enzymatic activity - secondary messengers, including KRAS and BRAF proteins. The assessment of the presence of mutations in the KRAS gene has become a standard element in the qualification of patients with advanced colorectal cancer for therapy with the use of monoclonal antibodies.
\end{abstract}

\section{Streszczenie}

Naskórkowy czynnik wzrostu (EGF) stymuluje proliferację wielu różnych typów komórek i odgrywa ważną rolę w powstawaniu i rozwoju nowotworów. Oddziaływanie EGF z komórkami jest możliwe dzięki receptorowi EGF (EGFR) zakotwiczonemu w błonie komórkowej. Nadmierna ekspresja EGFR występuje w ok. 25-82\% przypadków raka jelita grubego. Przyłączenie EGF do EGFR powoduje konformacyjną zmianę receptora, wzrost powinowactwa do sąsiednich receptorów, dimeryzację receptora i aktywację kinazy tyrozynowej w domenie wewnątrzplazmatycznej. Aktywacja EGFR prowadzi do inicjacji szlaku transdukcji sygnału do jądra komórkowego za pośrednictwem wielu białek o aktywności enzymatycznej - wtórnych przekaźników, w tym białek KRAS i BRAF. Ocena obecności mutacji w genie KRAS stała się standardowym elementem kwalifikacji pacjentów z zaawansowanym rakiem jelita grubego do leczenia z zastosowaniem przeciwciał monoklonalnych

\section{Introduction}

Epidermal growth factor (EGF) epidermal growth factor is the first of the growth factors isolated in the early sixties. The EGF stimulates the proliferation of many different types of cells and plays an important role in the formation and growth of tumours. Attachment of EGF or another ligand to EGF receptor (EGFR) results in a conformational change in the receptor, an increase in affinity for neighbouring receptors, receptor dimerisation, and activation of tyrosine kinase in the intraplasmic domain $[1,2]$.

The interaction of EGF with cells is possible by the EGFR receptor anchored in the cell membrane (c-ErbB-1/HER1). According to the classification of Fantel et al. regarding the division of receptors for growth factors, based on amino acid sequence similarities and tertiary structure, EGFR belongs to class 


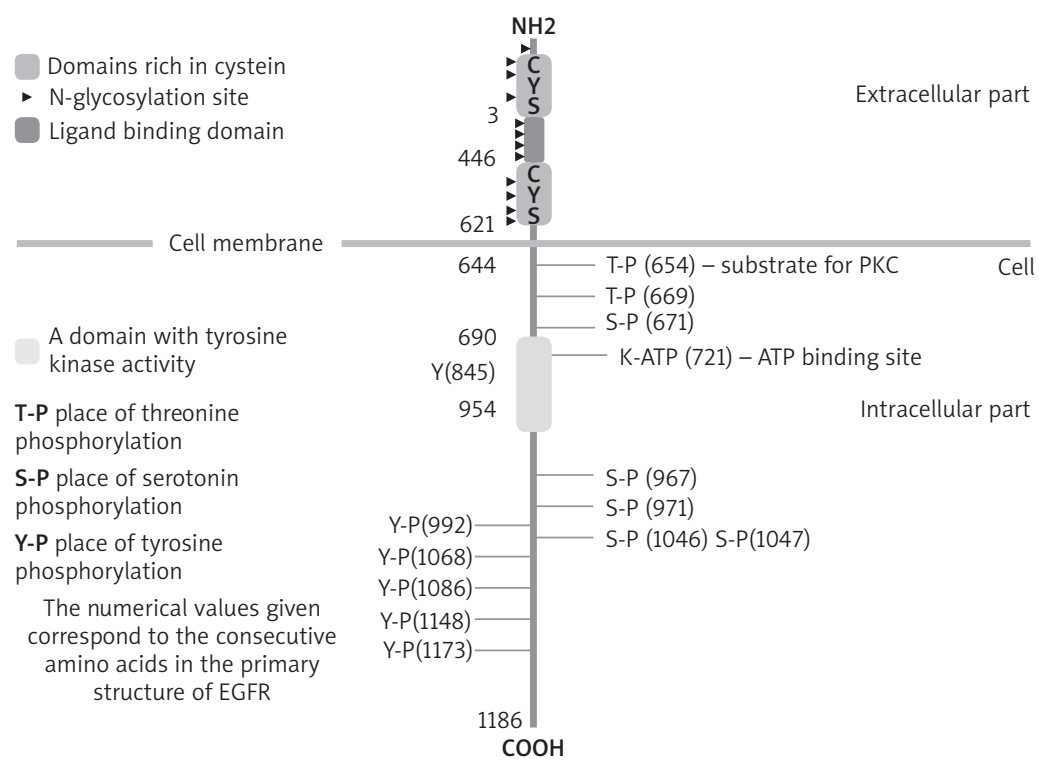

Figure 1. Structure of the human EGF receptor - linear diagram

I receptors, which in the extracellular part containing two domains rich in cysteine, and in the extranuclear part the domain exhibiting kinase activity tyrosine [2, 3] (Figure 1).

Up to now known ligands for EGFR, apart from EGF, include: transforming growth factor- $\alpha$ (TGF- $\alpha$ ), amphiregulin (AR), heparin-binding EGF-like growth factor (HB-EGF), betacellulin (BTC), cripto-1, Schwannoma-derived growth factor (SDGF), vaccinia growth factor (VGF), spitz, and lin-3 [4].

\section{Construction of EGFR}

In humans, the gene coding for EGFR is located on chromosome 7 . The $170 \mathrm{kDa}$ protein encoded by this gene consists of 1186 amino acids. There are two domains rich in cysteine in the extrathematical part of the EGFR. The ligand binds between these domains in the area between 313 and 446 amino acids. Twelve potential $\mathrm{N}$-glycosylation sites were found within the EGFR extragranular part. Glycosylation reduces receptor sensitivity to proteolytic enzymes. The oligosaccharides of the extracellular receptor are subject to post-translational phosphorylation [1, 2].

The EGFR is anchored in the cell membrane by means of a short, single, hydrophobic domain. A fragment of the intracellular EGFR displaying tyrosine kinase activity has a conserved structure with high homology to Src family proteins. Lysine at position 721 is involved in the binding of ATP and is necessary for the tyrosine kinase to function. The replacement of lysine by methionine abolishes the cell's response to EGF stimulation. Two EGFR classes are distinguished in the membrane of the majority of cells: high $(\mathrm{Kd}=3$ $\left.\times 10^{-10}\right)$ and small $\left(\mathrm{Kd}=2 \times 10^{-9}\right)$ affinity to the ligand. These receptors are present in the cell membrane in a ratio of about $1: 10$. Both receptor classes are encoded by the same gene. The probable cause of differences in ligand affinity can be oligomerisation of receptors or interaction with unfamiliar membrane or cellular proteins $[3,4]$.

\section{The mechanism of transmitting the signal to EGFR}

Attachment of EGF or another ligand to EGFR results in a conformational change in the receptor, an increase in affinity for neighbouring receptors, receptor dimerisation, and activation of tyrosine kinase in the intraplasmic domain [2,3].

Proteins that are substrates of tyrosine kinase can be divided into three groups:

1) enzymes that migrate to the cell membrane, are activated by EGFR tyrosine kinase and have good access to their substrates, and are located in the cell membrane or closely related to it. These include: $\mathrm{C} \gamma$ phospholipase (PLC $\gamma$ ), PI3-K phosphatidylinositol 3-kinase, GTP-Azote activating protein Ras (GAP), protein tyrosine phosphatase (SHP-2), JAK proteins;

2) proteins lacking enzymatic activity, so-called adapter proteins mediating between EGFR tyrosine kinase and other proteins involved in signal transduction pathways, e.g. growth-factor receptor-bound2 (Grb2), Shc, and Nck [3, 4];

3) structural proteins, responsible for rapid changes in the cell membrane and cytoskeleton.

Many studies have shown that EGF increases the proliferation of keratinocytes, mammary epithelial cells, cornea, gastrointestinal tract, trachea, lungs, as well as endothelial cells, fibroblasts, and glial cells. EGF significantly accelerates the healing of gastrointestinal ulcers, corneal ulcers, and burns, enhancing 
re-epithelialisation of these wounds; however, due to the documented contribution of EGF and its receptor in neoplastic transformation, the use of this cytokine is limited in therapy [2, 4].

Activation of EGFR in cancer cells is not only associated with proliferation stimulation, but also with protection against apoptosis:

1) Blocking EGFR in normal human keratinocytes was accompanied by a decrease in the expression of the BCL-xL protein that protects cells from apoptosis. This resulted in a significant decrease in the tolerance of the tested keratinocytes to proapoptotic signals sent to them.

2) The reduction of EGFR expression at the level of mRNA and protein by $\beta$-carotene in the dysplastic cells of the uterine cervix correlated with the occurrence of apoptosis in these cells. It is believed that the protective role of $\beta$-carotene in the multistage process of cervical carcinogenesis is associated with a decrease in the amount of EGFR capable of activating.

3) The use of a selective EGFR tyrosine kinase inhibitor that completely prevents the activation of EGFR tyrosine kinase resulted in cell cycle suppression and the induction of apoptosis in various cancer cells. A similar effect was observed in the case of tumour cells transformed with human papillomavirus (HPV16).

4) Activation of EGFR by EGF in the MDA-231 cell line protected cells against apoptosis induced by the administration of protein synthesis inhibitors, such as cycloheximide and ricin. The protective effect of EGF on these cells can be the result of EGFR activation of protein kinase $\mathrm{C}$ (PKC). Treatment of cells with staurosporine, a $\mathrm{C}$ kinase inhibitor, in a dose-dependent manner, weakens the protective effect of EGF.

5) Detection of the relationship between EGFR overexpression and hyperproliferation and protection of cells against apoptosis resulted in the development of new methods of treatment of cancers resistant to previous treatment, based on different methods of EGFR inhibition [1-4].

Studies on cell lines characterised by EGFR overexpression have shown that in response to stimulation with high doses of EGF, these cells are inhibited by proliferation. It is presumed that the inhibition of these cells is caused by excessive activation of EGFR tyrosine kinase. The use of antibodies or inhibitors of tyrosine kinase, reducing its activity by $30-40 \%$, protected cells against inhibition of proliferation.

Many growth factors can affect both proliferation and cell differentiation. The effects of opposing effects by the same cytokine need not be associated with the activation of various intracellular signalling pathways. It may also be related to the duration of the activation of the same route. Transient or prolonged activation of ERKs in the PC12 cell line stimulated with EGF results in cell proliferation or differentiation, respectively. The prolonged duration of ERK activation in these cells was obtained by overexpressing EGFR. However, transient MAP kinase activation does not always lead to cell proliferation and prolonged activation for differentiation. There are other correlations in other cell lines [5].

There are a growing number of reports suggesting that the anti-proliferative effects of EGF are responsible for STAT proteins and, above all, STAT1 protein. In A431 MDA-MB-468 cells, in response to EGF, activation of STAT proteins occurs, which induces for up to $24 \mathrm{~h}$ upregulation of p21WAF1 - a cyclin-dependent kinase inhibitor. This protein blocks the passage of cells from the $\mathrm{G} 1$ phase to the $\mathrm{S}$ phase. Its excessive expression may be responsible for inhibiting cell proliferation after administration of EGF.

Further studies on the A431 and MDA-MB- 468 cell lines have shown that inhibition of cell proliferation in the presence of high doses of EGF is due to the induction of apoptosis. The evidence for the occurrence of apoptosis is the morphological change in cells. There are many hypotheses attempting to explain the proapoptotic effects of high doses of EGF on cells overexpressing EGFR. Some researchers associate the occurrence of apoptosis with an excessive number of promitotic signals reaching the cell through activated EGF receptors. This leads to dysregulation of signalling pathways in the cell, and instead of proliferation, there is inhibition of growth and induction of apoptosis.

There are also suggestions that the occurrence of apoptosis in the tested cell lines is associated with the c-Myc transcription factor. Elevated c-Myc concentration is observed in both proliferating cells as well as in cells that die as a result of apoptosis. Increased expression of c-Myc is detected in A431 cells after the use of large and small doses of EGF, but its contribution to the induction of apoptosis in these cells remains unclear. It is believed that the family of cysteine proteases, called caspases, is the major function in the signalling pathways to apoptosis. The best-known ones are caspase-1 (interleukin 1 $1 \beta$-converting enzyme - ICE) and caspase-3. The first of these may activate other caspases through limited proteolysis, e.g. caspase 3, which is attributed the ability to degrade numerous cellular proteins and induce cell death. Studies on A431 and MDA-MB-468 cells have shown that stimulation of EGF leads to an increase in caspase 1 activity. This increase is associated with the induction of gene expression for this caspase by STAT proteins. This suggests that EGF-induced apoptosis is associated with the activation of caspases by the STAT protein pathway. Caspases are synthesised in the cell in the form of inactive proenzymes. The EGF receptors transmit signals to proliferate and are assigned a significant role in the process of tumorigenesis. Under certain circumstances, they may participate in inhibiting the proliferation and induction of apoptosis. Understanding the factors that determine whether EGFR sends 
a signal for proliferation or apoptosis is therefore of clinical significance.

Data from clinical trials suggest that EGFR plays an important role in the development of colorectal cancer. A higher rate of expression of transforming growth factor $\alpha$ (EGF), epidermal growth factor (EGF) - EGFR ligands as well as EGFR, HER2, and HER3 receptors has been demonstrated on cancer cells of large intestine cancer than in cells adjacent to them, unchanged mucous membrane of this organ [4-6].

Excess EGFR expression is found in approximately $25-82 \%$ of colorectal cancer cases. The severity of EGFR expression correlates with the severity of the clinical disease and the risk of distant metastases. Activation of EGFR leads to the initiation of the signal transduction pathway to the cell nucleus, via a number of proteins with enzymatic activity - secondary messengers, including KRAS and BRAF proteins. The occurrence of mutations in the KRAS or BRAF gene means that these proteins are constantly active, regardless of the activation or inactivation of EGFR. Mutations in the KRAS gene are found in about 30-40\%, and mutations in the BRAF gene in about $8 \%$ of patients with colorectal cancer. Mutations in the KRAS and BRAF gene are mutually exclusive, i.e. there is no mutation in the BRAF gene in the presence of a mutation in the KRAS gene and vice versa, in the presence of a mutation in the BRAF gene, no mutations in the KRAS gene are detected. The presence of mutations in the KRAS gene or in the BRAF gene is a negative predictor of the response to treatment of patients with advanced colorectal cancer using monoclonal antibodies against EGFR. The assessment of the presence of mutations in the KRAS gene has become a standard element in the qualification of patients with advanced colorectal cancer for therapy with the use of cetuximab and panitumumab $[4,7,8]$.

\section{Monoclonal antibodies}

In 1983, Mendelsohn et al. synthesised a murine antibody that in cell cultures showed activity in inhibiting tumour cell proliferation both in vitro and in animal models. Cetuximab is a chimeric G1 immunoglobulin and a monoclonal antibody. It was registered for the treatment of colon cancer at the dissemination stage, after the failure of irinotecan-based chemotherapy. Indications for the use of cetuximab are based on the assumption that EGFR expression in immunohistochemistry is both a qualitative and quantitative predictor of response to cetuximab. Panitumumab is a fully humanised (G2 immunoglobulin) monoclonal antibody with strong affinity for the EGFR receptor. In studies, panitumumab demonstrated cetuximablike efficacy in patients with metastatic colorectal cancer, who have completed their response to standard treatment with cytostatics, but the humanised antibody is associated with fewer allergic reactions than the chimeric antibody cetuximab. Panitumumab has a high affinity for EGFR, approximately five-fold higher than cetuximab. The mechanism of action of monoclonal antibodies directed against EGFR is complex. Cetuximab and panitumumab bind specifically to the extracellular domain of EGFR, preventing EGF and TGF- $\alpha$ from binding to the receptor and, consequently, preventing its activation. These antibodies block EGFR dimerisation, tyrosine kinase phosphorylation, and receptor autophosphorylation and thereby inhibit the transmission of intracellular signals. The effect of cetuximab and panitumumab is to inhibit tumour cell proliferation, increase their apoptosis, and reduce the synthesis and secretion of pro-angiogenic factors such as interleukin 8 (IL-8) and VEGF. In addition, antibodies directed against EGFR impairs the repair of DNA damage caused by chemotherapy and radiotherapy in tumour cells [9-11].

\section{Conflict of interest}

The authors declare no conflict of interest.

\section{References}

1. Neumann JH, Jung A, Kirchner T. Molecular pathology of colorectal cancer. Pathologe 2015; 36: 137-44.

2. Fearon ER, Vogelstein B. A genetic model for colorectal tumorigenesis. Cell 1990; 61: 759-67.

3. Shan L, Li M, Ma J, Zhang H. PCR-based assays versus direct sequencing for evaluating the effect of KRAS status on anti-EGFR treatment response in colorectal cancer patients: a systematic review and meta-analysis. PLoS One 2014; 9: e107926.

4. Caiazza F, Elliott L, Fennelly D, Sheahan K, Doherty GA, Ryan EJ. Targeting EGFR in metastatic colorectal cancer beyond the limitations of KRAS status: alternative biomarkers and therapeutic strategies. Biomark Med 2015; 9: 363-75.

5. Cervantes A. Exploring better strategies for EGFR antibodies in colon cancer. Lancet Oncol 2014; 15: 549-50.

6. De Stefano A, Carlomagno C. Beyond KRAS: predictive factors of the efficacy of anti-EGFR monoclonal antibodies in the treatment of metastatic colorectal cancer. World J Gastroenterol 2014; 20: 9732-43.

7. Douillard JY. Panitumumab - FOLFOX4 treatment and RAS mutations in colorectal cancer. N Eng J Med 2013; 369: 1023-34.

8. Shen WD, Chen HL, Liu PF. EGFR gene copy number as a predictive biomarker for resistance to anti-EGFR monoclonal antibodies in metastatic colorectal cancer treatment: a meta-analysis. Chin J Cancer Res 2014; 26: 59-71.

9. Shinto E, Hashiguchi Y, Ueno H, Kobayashi H, Ishiguro M, Mochizuki H, Yamamoto J, Hase K. Pretreatment CD 133 and cyclooxygenase-2 expression as the predictive markers of the pathological effect of chemoradiotherapy in rectal cancer patients. Dis Colon Rectum 2011; 54 : 1098-106.

10. Stremitzer S, Sebio A, Stintzing S, Lenz HJ. Panitumumab safety for treating colorectal cancer. Expert Opin Drug Saf 2014; 13: 843-51. 
11. Thomaidis T, Maderer A, Formentini A, Bauer S, Trautmann M, Schwarz M, Neumann W, Kittner J, Schad A, Link KH, Rey J, Weinmann A, Hoffman A, Galle P, Kornmann M, Moehler M. Proteins of the VEGFR and EGFR pathway as predictive markers for adjuvant treatment in patients with stage II/III colorectal cancer: results of the FOGT-4 trial. J Exp Clin Cancer Res 2014; 33: 83.

\section{Address for correspondence:}

Monika A. Kozłowska-Geller

Department of Physiology

Institute of Medical Science

Faculty of Medicine and Health Science

Jan Kochanowski University

al. IX Wieków Kielc 19, 25-317 Kielce, Poland

Phone: +48 41602390428

E-mail: monika.kozlowska.chir@onet.pl 